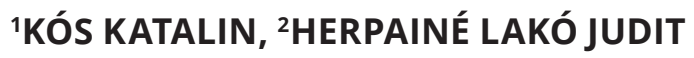

\title{
A CSALÁD SZEREPE AZ EGÉSZSÉGKÁROSÍTÓ SZOKÁSOK TÜKRÉBEN
}

\section{THE ROLE OF THE FAMILY AS RELATED TO HARMFUL BEHAVIOR}

\author{
'Széchenyi István Egyetem \\ 2Eszterházy Károly Egyetem \\ lako.judit@uni-eszterhazy.hu
}

\begin{abstract}
Absztrakt
Szakirodalmi adatok bizonyítják, hogy a családi nevelés és annak befolyásoló ereje milyen jelentős mértékben hat az egyén életének minden területére, kiemelten a mindennapos döntéshozó képességre. Jelen kutatás káros szenvedélyekkel kapcsolatos eredményei azt igazolták, hogy a szülők szokásai jelentős mértékben kihatnak gyerekeik élvezetiszer-használathoz való viszonyulására és egészség-magatartására. Az egészségesebb életmódra törekvés a vizsgált minta többségénél fönnáll, azonban a bevésődött szokások korlátozó erővel bírnak a megvalósítás során.
\end{abstract}

Kulcsszavak: család, nevelés, egészségmegőrzés, szokások

\begin{abstract}
Extensive literature proves that family education and parents greatly influence the individual's everyday habit in every field of life, especially on their decision-making process. The results of this paper on addiction confirms that that parents' bad habits directly impacts their children's attitude towards excise goods (like tobacco, alcohol) and also their health behaviour. The vast majority of survey respondents claimed that they want to live a healthier lifestyle, however, they cannot break bad, imprinted habits and change their behaviour.
\end{abstract}

Keywords: family, education, health prevention, habit 


\section{Bevezetés}

A gyermek sikeres nevelésében a kulcs a normák elsajátításában kereshető, mellyel a társadalomba való beilleszkedésének folyamatát segítjük elő. A szocializáció azonban olyan jelentéssel is bír, mely meghatározza az egyén fejlődését, miközben a különböző társadalmi szerepekkel azonosul (Andorka, 2006). A szocializáció mértéke nagyban függ a részvétel idejétől és intenzitásától, ezért azokat a közegeket tekinthetjük szocializációs közegnek, amelyek az előbb említett tulajdonságoknak megfelelnek (Majzikné Lichtenberger, 2008). Fontos megjegyezni azonban, hogy a szocializációs színterek hatása nagyban függ attól, hogy az egyének hány társadalmi csoportba vagy helyzetbe töltik el életük egy-egy részét (Nagy és Székely, 2010).

A gyermek beleszületik egy adott mikrokörnyezetbe, és az ott látott és szerzett tapasztalatokat, normákat elsajátítja, azonosul velük, és a későbbiekben ez mintaként jelenik meg előtte (Solymosi, 2004). A család az egyetlen szocializációs közeg, amely egész életen át tart, és jelentős befolyásoló tényezőként mutatkozik meg (Bodonyi és mtsai., 2006; Csepeli, 2006), és az egyik legjelentősebb szerepet játssza a gyermekek szocializációjában, normákhoz való hozzáállásukban.

Fontos kiemelni, hogy az egészség nemcsak cél, hanem erőforrás is, ami segít a mindennapokban (Bognár, 2019). Ez az erőforrás csak abban az esetben tartható fent, ha az egészségünk minden dimenziója (fizikai, mentális, szociális) megfelelően és harmónikusan müködik (Kósa, 2005). Egészséges életmódunk megteremtéséhez nélkülözhetetlen a megfelelő napirend és a szokásrend kialakítása (Pál és mtsai, 2005). Az ideális napirend kialakítását fontos már kisgyermekkorban elkezdeni, mivel ez hatással lesz később a tanulási folyamatokra és eredményekre. A nevelés szerepe elengedhetetlen a gyerek életében és szokásai kialakításában (Busi, 2004). A családnak kiemelt szerep jut a gyermek mozgásos életének megformálásában, hiszen a szülők felelőssége a gyermek számára az optimális napirend kialakítása, melyhez hozzátartozik a rendszeres testmozgás (Bognár és mtsai., 2006).

\section{Család szerepe az egészséges életmód kialakításában, korunk népbeteg- ségei}

A család szerepe az egészségre nevelés folyamatában igen komplex, mivel rengeteg szerep- és feladatkörrel rendelkezik. A népbetegségek hátterében gyakran a stressz áll, mely akkor fordul át tényleges betegségi tünetté, mikor a családi közeg már nem elégíti ki a funkciójának megfelelő szerepet. Azok az emberek, akik stabil és megfelelő lelki, szociális és fizikai háttérrel rendelkező családból származnak, genetikától függetlenül könnyebben képesek kezelni a stresszt, és uralkodni tudnak a hajlam fölött.

A család feladata a védelem és folyamatos támogatás biztosítása mellett a világra és életre vonatkozó információk összegyűjtése és átadása. Ezek a ténye- 
zők ugyanis a legtöbb esetben észrevétlenül a szülőkön keresztül direkt befolyásoló jelleggel hatnak a gyerek viselkedésére és jellemfejlődésére, kiváltképp értékítéletére. A család és a mentális egészség viszonya már az 1960-as évektől központi témaként szerepelt a családkutatók körében. A támogatásnak mint funkciónak rendkívül fontos szerep jut a család rendszerének feladatai között. Ezeket a támogató funkciókat Gerald Caplan gyűjtötte össze a legátfogóbban, melyek a következők szerint foglalhatók össze (Bodonyi és mtsai., 2006):

A gyerek sikeres alkalmazkodásához hozzájárul, hogy a család által mutatott példák és információk milyen rendezési elv szerint következnek egymás után, és hogyan érvényesülnek a mindennapi élet során, továbbá hogy milyen értékek, normák szerint él és alkot egy egységes képet a világról. A család rendelkezik egy kontrollfunkcióval is, mely a tagok magatartását egyéni vagy csoportos véleményalkotással befolyásolja. Ez tulajdonképpen a forrása az egyén önértékelésének, énképének és identitásának. A véleményalkotással a család tagjai befolyásolják egymás gondolait, cselekedeteit és irányítják egymást.

A család fontos feladatának számít továbbá az érzelmi teherbírás fejlesztése is, mely nélkülözhetetlen az egyén krízishelyzeteinek átvészelésében és a problémamegoldásban. Ettől határozza meg azt, hogy konstruktívan és körültekintően oldja meg a problémáit, vagy ellenkező esetben kicsúszik uralma alól az irányítás, és újabb problémákat szül vele.

A család szintén fontos szerepe a pihenés és regenerálódás biztosítása és az érzelmi egyensúly megteremtése, mely a közeg fokozott érzelmi elfogadása miatt képes létrejönni. Így lehetősége nyílik az egyénnek a családon kívül eső szituációk helyes megoldására. Ez a szerep akkor is elsőbbséget élvez, mikor egy rászoruló családtagról van szó, akinek a kialakult problémáiban gyakorlati, konkrét módon segédkeznek.

Nélkülözhetetlen továbbá a családi közeg értékelő és bíráló szerepe is, ugyanis a tagok feltételezik egymásról a jóindulatot a kritikák számbavételében és viselésében is. Nem véletlen tehát, hogy ezekre többnyire jobban odafigyelnek, és fogékonyabbak egymás javaslataira. A család tagjai egymáshoz viszonyítva bírálják saját magukat, ezért az esetek többségében vonatkoztatási pontként is szolgálnak egymásnak.

Ezen kívül a család rendelkezik jogi és népességutánpótlási funkcióval is. Az előbb említett funkciók akkor múködnek sikeresen és nagyfokú hatékonysággal, ha a tagok felelősségteljesen viselkednek nemcsak magukkal, de egymással szemben is, nyíltan kommunikálnak, kapcsolataik alapja a kölcsönösség, és elfogadják a család kontrollfunkcióját. Nélkülözhetetlen kitétele továbbá a generációk közti kapcsolatépítés és -ápolás, valamint a mikromiliő és az egyetértés. Lényege tehát, hogy úgy illeszkedjen be környezetébe, hogy közben hü maradjon saját elveihez és elvárásaihoz. A sport és a testedzés jelentőségének elsajátítása fontos családi értéket képvisel, ugyanis nélkülözhetetlen a család egészségtudatos magatartásának szempontjából.

Mindezek alapján a tanulmány célja az volt, hogy a család szerepét bemutassuk az egészségkárosító tényezők tekintetében. 


\section{Családi háttér befolyásoló ereje egy empirikus vizsgálat tükrében}

Kutatásunk három egyetem három különböző karán zajlott, az egri Eszterházy Károly Egyetem Természettudományi Kara, a budapesti Eötvös Loránd Tudományegyetem Bölcsészettudományi Kara, valamint a Budapesti Gazdasági Egyetem Pénzügyi és Számviteli Kara alkotta a mintát. Az Eszterházy Károly Egyetem Természettudományi Karán a kitöltők között voltak rekreációszervező és egészségfejlesztő, sportszervező, programtervező informatikus és osztatlan tanári alapszakos hallgatók is. Az Eötvös Loránd Tudományegyetem Bölcsészettudományi Karán tanulók közül anglisztika és osztatlan tanári alapszakos hallgatók töltötték ki a kérdőívet. Ezen felül a Budapesti Gazdasági Egyetem Pénzügyi és Számviteli Karának pénzügy-számvitel, gazdálkodás és menedzsment, emberi erőforrások és gazdaságinformatika alapszakos hallgatói közül kerültek ki a kitöltők. A különböző egyetemeken különböző szakokon tanuló hallgatók által növelhető a diverzitás, mindemellett a minnta sokszínűségével pontosabb képet ad az egyetemisták szokásairól.

A vizsgálati csoport nappali tagozatos egyetemistákból állt, akiket zárt végú kérdőívvel kérdeztünk meg a család szerepéről. A minta életkora 19 és 28 éves kor között oszlott meg. A nemek arányát tekintve jól látható, hogy a válaszadók 26,1\%-a (49 fö) férfi volt, míg a 73,9\%-uk (139 fö) nő volt.

Eredményeink alapján elmondható, hogy a válaszadó egyetemisták az édesanyjuk (71,8\%) és az édesapjuk (53,1\%) véleményét tartották számukra a legmeghatározóbbnak. A harmadik személy, akire a diákok több mint 42,5\%-a a fontos döntésekben hallgat, az a párjuk volt.

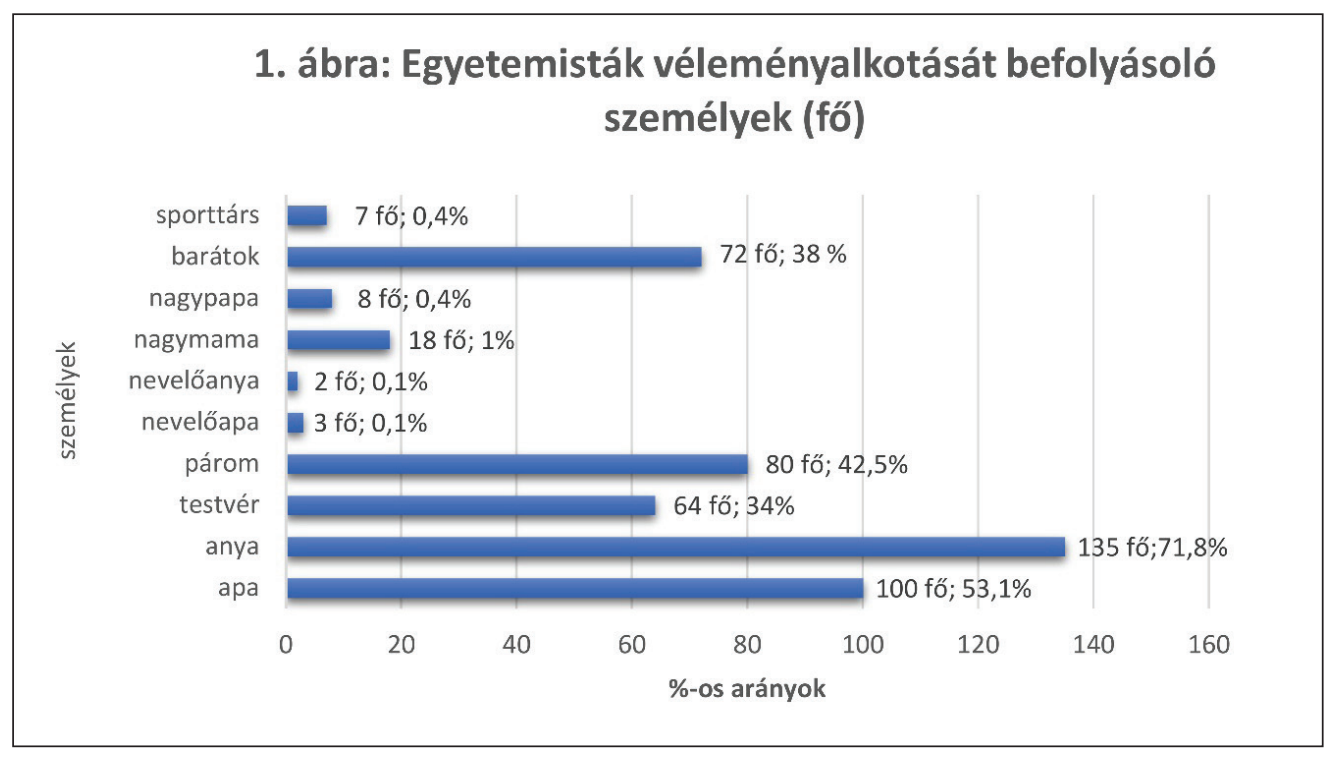

1. ábra: Egyetemisták véleményalkotását befolyásoló személyek (fő) 
Az egyetemista hallgatók körében igen elterjedt szabadidős tevékenység a szórakozóhelyek látogatása. A 19-28 éves kor közé eső fiatalok 41\%-a havonta jár szórakozóhelyekre, 27\%-uk naponta, 19\%-uk évente, és 13\% hetente látogatja ezeket a helyeket.

\section{2. ábra: Szórakozóhely látogatási arány (fő)}

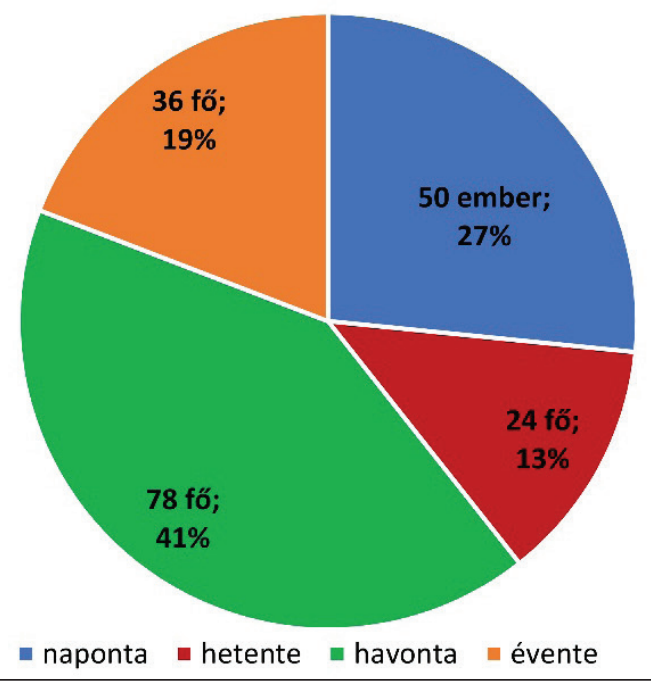

2. ábra: Szórakozóhely-látogatási arány (fő)

A legjobb feszültségoldó technikák közül a hallgatók 71,8\%-a a zenét tette az első helyre, második helyre a többség az alvást választotta 67,7\%-ban. A dobogó harmadik helyét a sport nyerte el 62,2\%-kal. Jól látható az is, hogy körülbelül egyforma arányban a hallgatók 25,5\%-a a bulizást, 23,4\%-a az alkoholfogyasztást és $25 \%$-a a vásárlást is a leggyakrabban alkalmazott feszültségoldó módszernek választotta. 


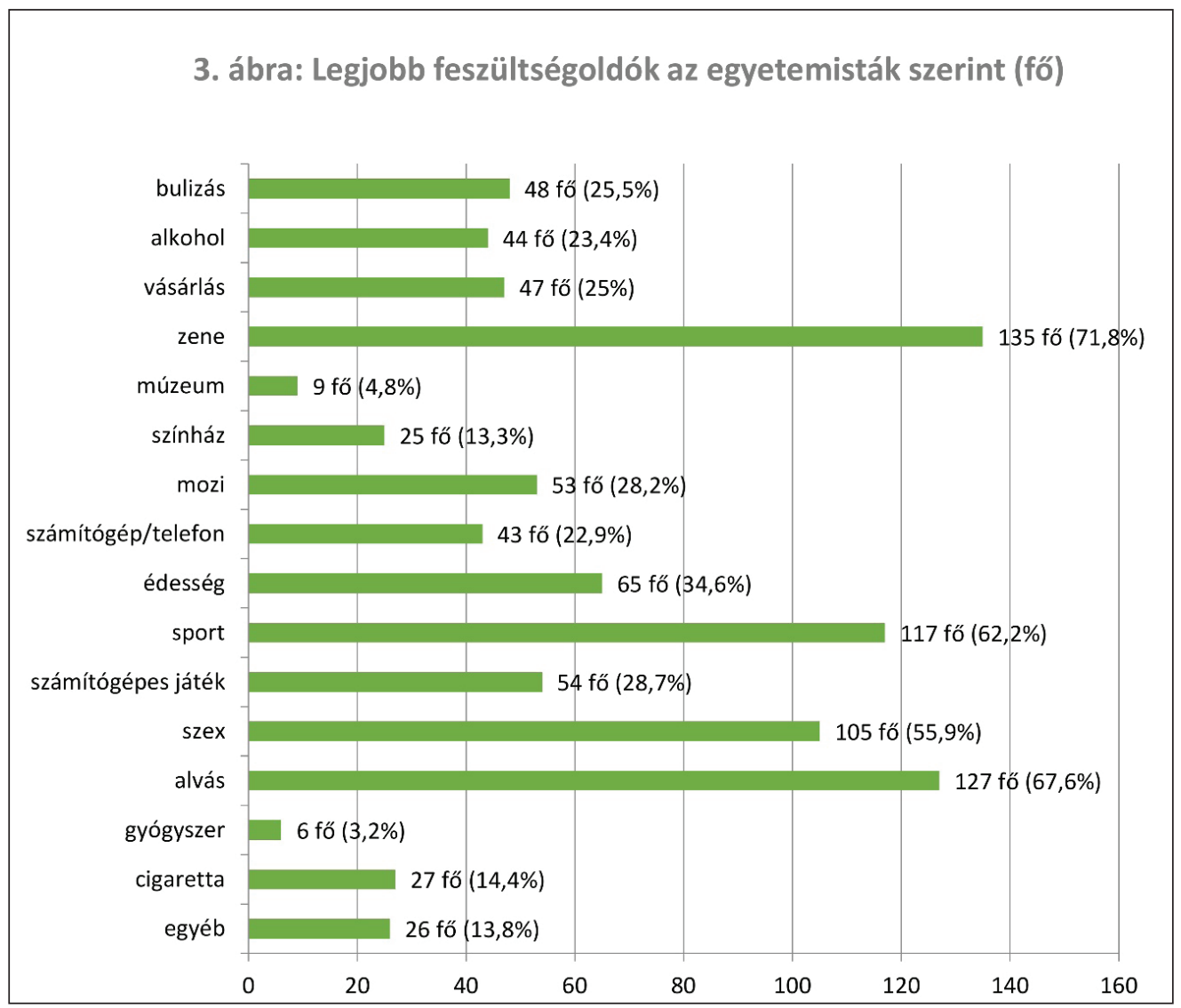

3. ábra: Legjobb feszültségoldók az egyetemisták szerint (fő)

Ez azt mutatja, hogy a frusztrációjukat, a stresszt a megkérdezettek harmada alkohollal, illetve pénzköltéssel kívánja orvosolni. A számítógép/telefon (22,9\%) használata és a különböző számítógépes játékok (28,7\%) is közel hasonló arányt mutatnak, amelyből könnyen függőségi állapot is kialakulhat. A cigaretta 14,4\% véleménye szerint a legjobb feszültségoldó, amelyből arra következtethetünk, hogy körülbelül minden hetedik egyetemista a cigarettához nyúl egy-egy stresszhelyzetben. Amennyiben az elsődleges példamutató közeg magatartása a felnőttek esetében jóváhagyja a dohányzást, ezt a példát fogja követni a gyermek is. A feszültségoldók között megjelent a gyógyszer is 3,2\% esetében, ami egy alacsony értéknek számít. Azonban a fiatal felnőttek esetében a feszültségoldó gyógyszerek tartós használat esetén ugyanúgy függőséghez vezethetnek. Bizakodásra adhat okot, hogy az első három helyen a természetes technikák állnak (zene, alvás és sport).

A megkérdezettek mindössze 16\%-a nem fogyaszt szeszes italt. 10\% alkalmanként egy-, 22\% már alkalmanként 2-3 pohár, 11\% egy üveg/doboz (051,5 liter) és $16 \%$ több üveg/doboz (05-1,5 liter) alacsony alkohol tartamú italt 
fogyaszt. A fönnmaradó 23\%-ból 7\% 1-2 feles pohárnyi-, 16\% 3-5 feles pohárnyi és 2\% egy üveg (0.5-0.7 liter) tömény szeszes italt fogyaszt minden alkalomkor. Fontos kiemelni, hogy ebben a mintában a szülő feladata már nem a tiltás, hanem a mértékletességre nevelés és példamutatás.

\section{4.ábra: Szeszes ital fogyasztás mértéke (fő)}

4 fö;

$2 \%$
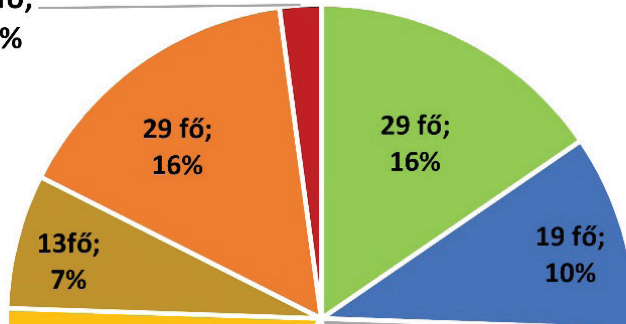

29 fö;

$16 \%$

42 fö;

$22 \%$

23 fö;

$11 \%$

nem fogyasztok

- alkalom/ egy pohár alacsony alkohol tartamú ital

alkalom/ 2-3 pohár alacsony alkohol tartamú ital

alkalom/ egy üveg/doboz (0.5-1,5 liter) alacsony alkohol tartamú ital

alkalom/ több üveg/doboz (0.5-1,5 liter) alacsony alkohol tartamú ital

- alkalom/ 1-2 feles pohárnyi tömény szeszes ital

alkalom/ 3-5 feles pohárnyi tömény szeszes ital

• alkalom/ 1 üveg (0.5-0.7 liter) tömény szeszes ital

4. ábra: Szeszesital-fogyasztás mértéke (fő)

A dohányzási szokások vizsgálata során kiderült, hogy 4\% napi 20 szál (1 doboz) cigarettát szív el, ami tartósan nagyon súlyos következményekkel járhat. További 6\% már napi 10 szállal is beéri, és 10\% esetében ez a mennyiség napi pár szálra csökken. Viszont 11\%-uk alkalmanként szokott csak rágyújtani. 
Ez azt mutatja, hogy már ebben a korban is $21 \%$ aktívan dohányzik, $11 \%$ pedig épp most szokik rá. Ez azt jelenti, hogy minden harmadik kitöltő dohányzik valamilyen rendszerességgel.

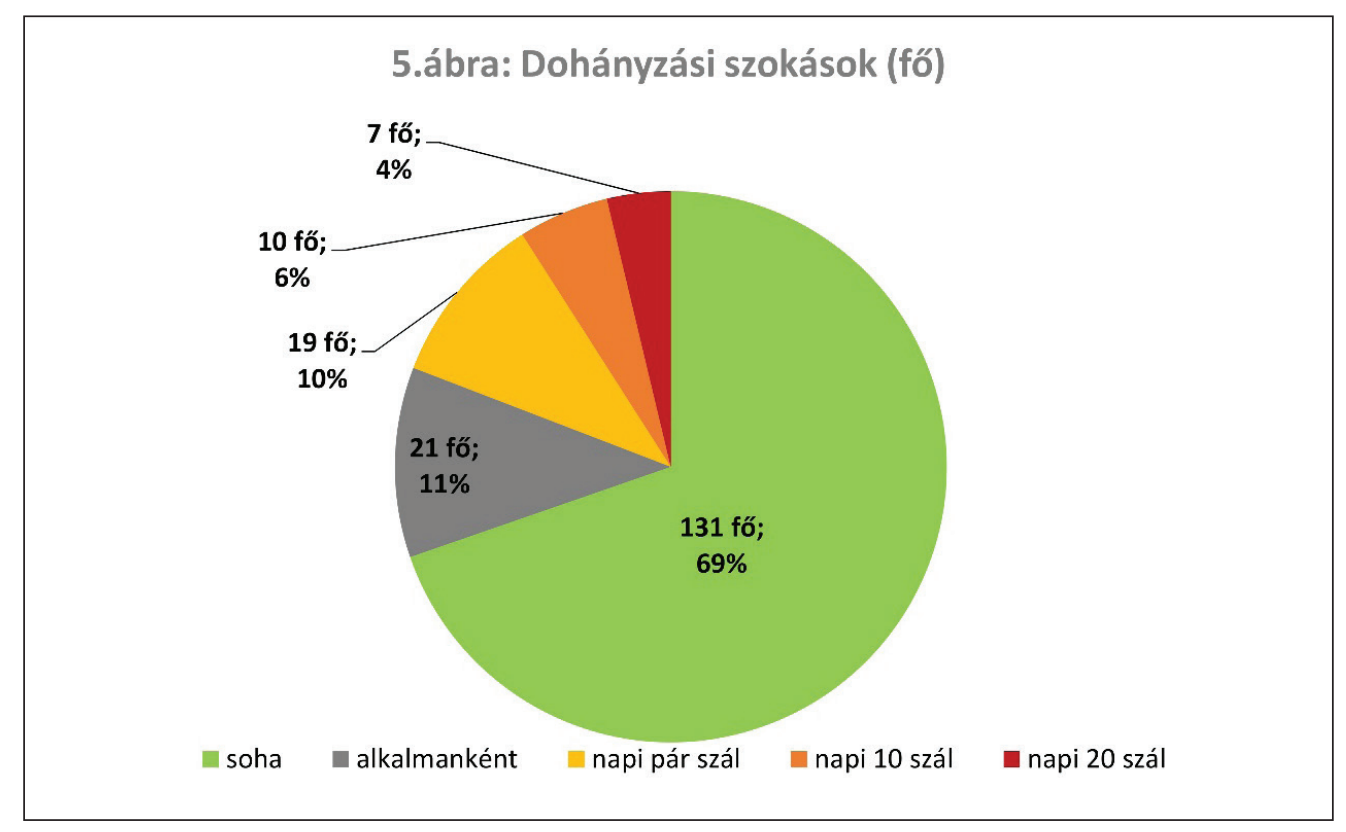

5. ábra: Dohányzási szokások (fö)

A Központi Statisztikai Hivatal 2014-es mérései a 18-34 éves korosztály tekintetében hasonló adatokról számoltak be a dohányzási hajlandóság tekintetében. A magyar lakosság 18-34 év közé eső korcsoportjának 29\%-a tartozik a rendszeresen dohányzók közé (KSH, 2014).

A kábítószer fogyasztásnál ez az arány csak kis mértékben tér el az előbbitől, ugyanis míg 69\% nem dohányzik, csupán 10\%-kal nagyobb azok aránya, akik nem fogyasztanak kábítószert (79\%). Ehhez képest 17\% kipróbált már valamilyen drogot, 3\% évente és 1-1\% heti, illetve havi rendszerességgel fogyaszt valamilyen szert. 


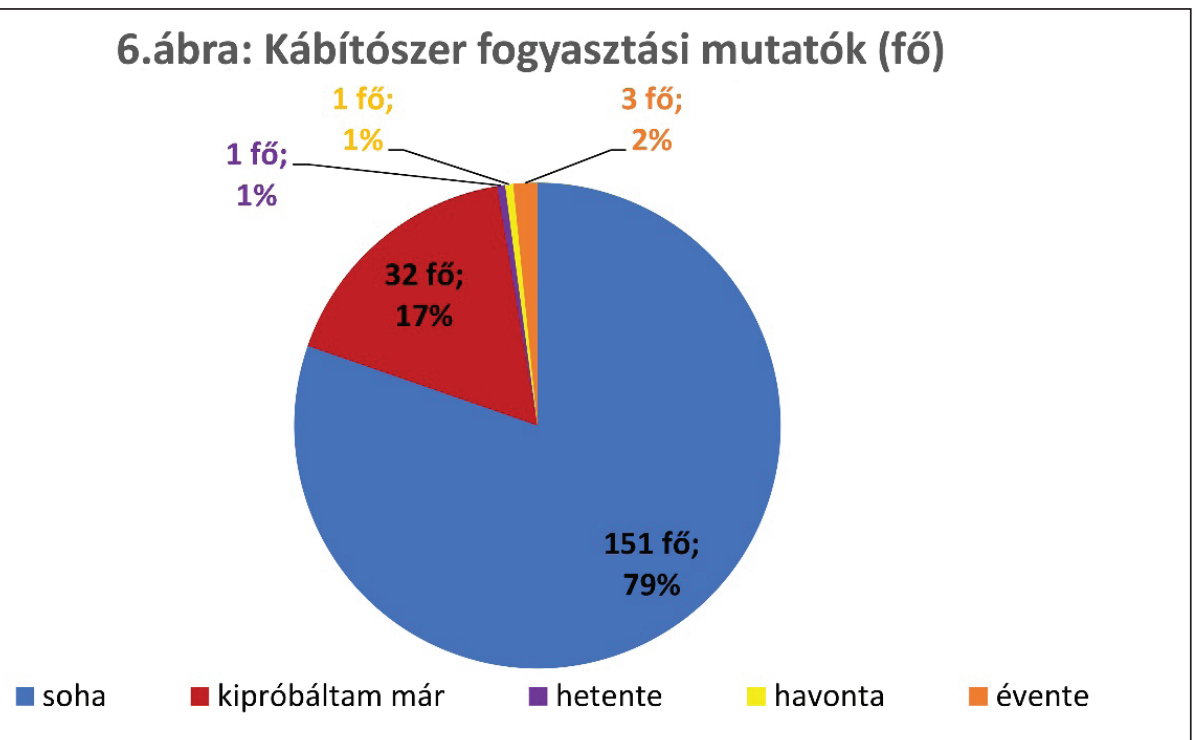

6. ábra: Kábítószer-fogyasztási mutatók (fő)

Amennyiben ezek az adatok a 19-28 évesek között a fogyasztás irányába nőnek, súlyos függőséghez, életminőség-romláshoz, anyagi károkhoz vezet, és büntetőjogi következményt von minden esetben maga után. A hallgatók 36\%ának családjában fordul elő, hogy valamilyen élvezeti szert használnak, így a családi minta szerepe nem pozitív.

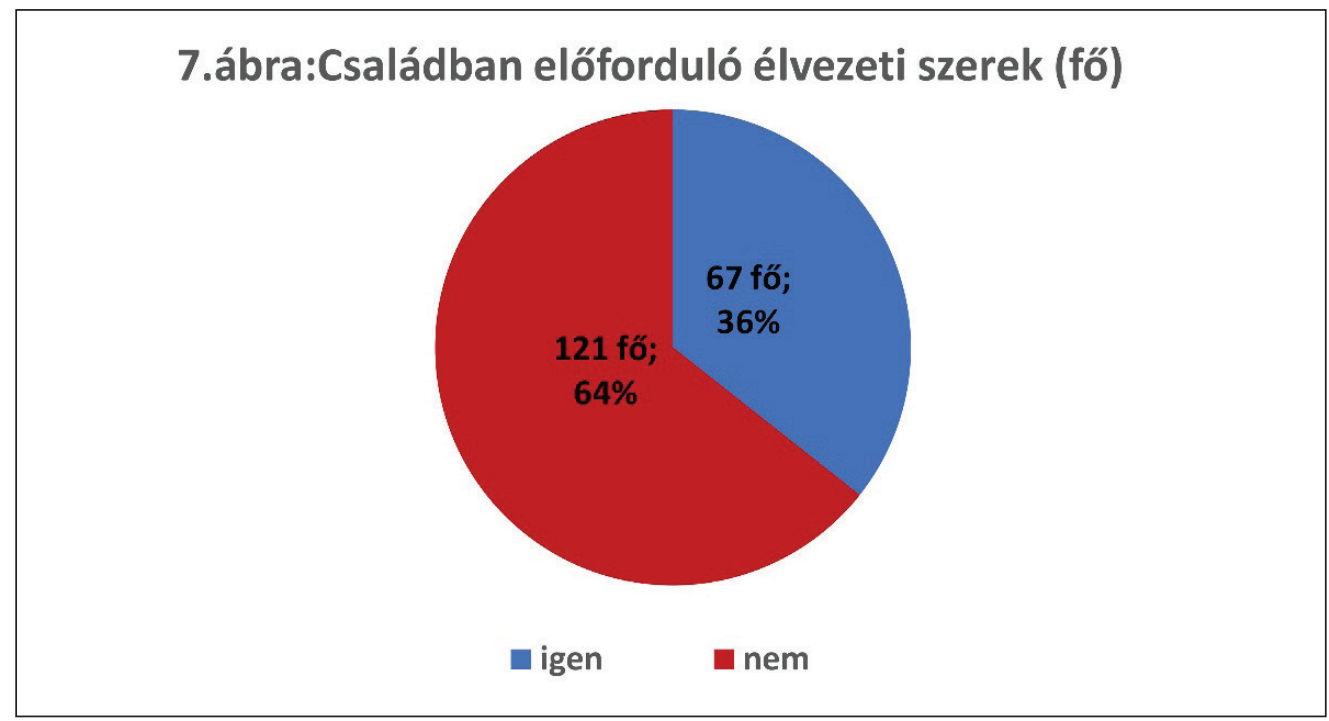

7. ábra: Családban előforduló élvezeti szerek (fő) 
A rendszeresség tekintetében a válaszadók 57\%-ának családjában napi többször is fogyasztanak ilyen élvezeti szereket.

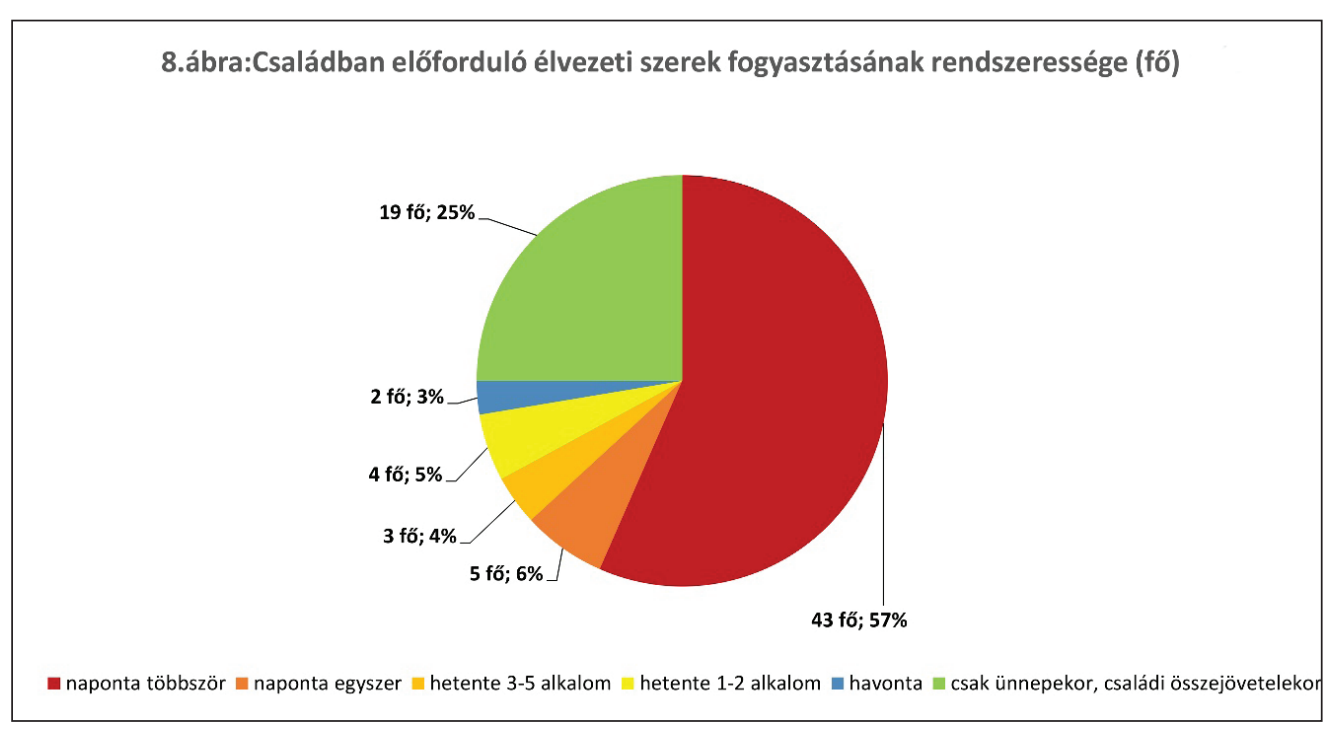

8. ábra: Családban előforduló élvezeti szerek fogyasztásának rendszeressége (fő)

Hasonló arányban válaszolták a hallgatók, hogy családon belül naponta egyszer (6\%), hetente 1-2-szer (5\%), hetente 3-5 alkalommal (4\%), illetve havi gyakorisággal (2\%) élnek a fent említett élvezeti szerek bármelyikével. Ezt összegezve kimondható, hogy az egyetemisták háromnegyedének (75\%) családja valamilyen rendszerességgel élvezetiszer-függő. Ez azt jelenti az előző adatokkal összevetve, hogy jelentős mértékben beszélhetünk a család szerepéről a negatív példamutatás és az addikció kialakulásának esetében.

Ezzel szemben bizakodásra adhat okot, hogy megkérdezettek 40\%-a az étrendjén és az étkezési szokásain változtatna, 35\% több mozgást, több sportot is beiktatna az életébe. A kitöltők $6 \%$-a úgy vélte, hogy kevesebb édességet kellene fogyasztania, 5\%-uk ha tehetné, kevésbé stresszes életet élne. Mindössze $4 \%$ választaná a dohányzásról való leszokást, és csak 3\% szeretne kevesebb alkoholt, illetve $2 \%$ kevesebb kávét inni. Mindössze $1 \%$ válaszolta a több alvást is, azonban $4 \%$ semmiben nem kíván változtatni jelenlegi életmódján. 


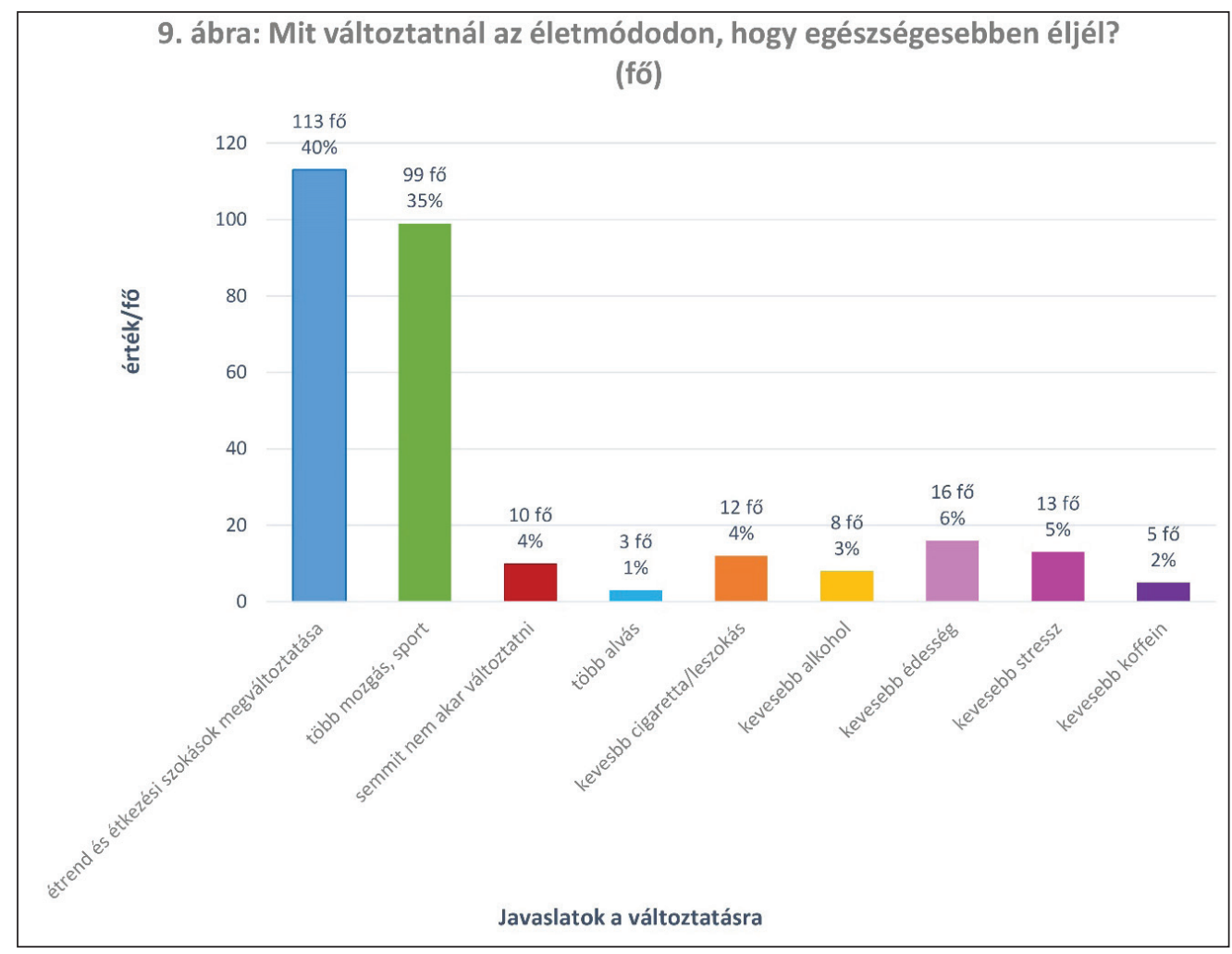

9. ábra: Mit változtatnál az életmódodon, hogy egészségesebben éljél? (fő

\section{Megbeszélés}

Az empirikus kutatás azt kívánta megerősíteni, hogy nemcsak gyerekkorban, hanem még fiatal felnőttkorban is a családnak van szerepe a különféle szokások és a pozitív egészség-magatartás kialakításában (Konczos és mtsai., 2012). A társak és a média mellett az elsődleges szocializációs közeg szerepe még a fiatal felnőttek tekintetében is jelentőséggel bír az egyén életében (Bognár és mtsai, 2010). A kutatás során az eredmények azt igazolták, hogy nagyobb arányban fordulnak elő káros szenvedélyek azoknál az embereknél, akiknek családjában is élnek hasonló élvezeti cikkekkel.

A döntés fejben születik meg, az egyén cselekszik. Az egyének családokat, a családok társadalmat alkotnak. Minél több egyén dönt a helyes életvitel mellett, annál több család fog tenni kollektívan egy jobb, egészségesebb társadalomért.

A továbbiakban érdemes a közoktatás egészséget és sportot érintő tapasztalatait összevetni a fiatal felnőttek érték- és szokásrendszerével és egészség-magatartásával (Olvasztóné és mtsai, 2007). Korábbi kutatások szoros kapcsolatra hívták fel a figyelmet, melyet több oldalról érdemes lenne vizsgálni (Huszár és Bognár, 2006). 


\section{Felhasznált szakirodalom}

Balázs Imre József (2011): Korunk. Budapest, Korunk Baráti Társaság Kiadó.

Bodonyi Edit, Busi Etelka, Hegedűs Judit, Magyar Erzsébet, Vizely Ágnes (2006): Család, gyerek, társadalom. Budapest, Bölcsész Konzorcium.

Bognár József (2019): A testnevelés értékorientációja. Új Pedagógiai Szemle, 69:3-4, 100-108.

Bognár József, Trzaskoma-Bicsérdy Gabriella, Révész László, Géczi Gábor (2006): A szülők szerepe a sporttehetség-gondozásban, Kalokagathia 44:(12.) pp. 86-95.

Bognár J., Gangl J., Konczos Cs., Fügedi B., Geosits B. K., Agócs A. (2010): How are quality of life and preferred values viewed by Hungarian adults? Journal of Human Sport and Exercise, 5:1. 84-93.

Busi Etelka (2004): Multimédia és pedagógia. In. http://edutech.elte.hu/ multiped/ped_03/ped_03.pdfLetöltés ideje: 2018.01.14.13:31 h.

Cselkó Zsuzsa, Kovács Gábor (2013): Dohányzási szokások Magyarországon: az utóbbi évtized felméréseinek elemzése. Orvosi Hetilap, 154 (37). 1454-1468.

Csepeli György (2006): Szociálpszichológia. Budapest, Osiris Kiadó.

Huszár A., Bognár J. (2006): Fiatal felnőttek testkultúrája, avagy az iskolai testnevelés felnőttkori hatásai Magyarország és Finnország példáján. Új Pedagógiai Szemle, 56:6. 107-114

Konczos Cs., Bognar J., Szakaly Z., Barthalos I., Simon I., Olah Zs. (2012): Health awareness, motor performance and physical activity of female university students, Biomedical Human Kinetics, 4:(1) 12-17.

Kósa Karolina (2005): Egészségfejlesztés alapismeretek pedagógusok számára, $\mathrm{Az}$ egészség és az egészséget meghatározó tényezők, Egészségügyi Minisztérium.

KSH (2003-2016): Standard halálozási ráta. In. http://www.ksh.hu/thm/2/ indi2_8_1.html 2018.04.14.10.56. h.

KSH (2015): Statisztikai Tükör In. https://www.ksh.hu/docs/hun/xftp/stattukor/ elef14.pdf 2019.11.15.10.56. $\mathrm{h}$.

Majzikné Lichtenberger Krisztina (2008): Szocializáció a posztmodern társadalomban és ennek hatása a fiatalok családképére, In. http:// nevelestudomany.phd.elte.hu/vedesek/2008/PhD_2008_Majzikne_ Lichtenberger_Krisztina.pdf

Nagy Ádám, Székely Levente (2010): Családon innen, iskolán túl, A harmadlagos szocializációs közeg és az ifjúságügy mint önálló terület elméleti alapjai, Budapest, Excenter Kiadó. 
Olvasztóné Balogh Zsuzsanna, Bognár József, Gangl Judit, Polgár Tibor, Fügedi Balázs (2007): Felnőttek érték- és tevékenységrendszerének feltárása. Egészségfejlesztés 48:5-6 pp. 7-13.

Pál Katalin, Császár Judit, Huszár Anikó, Bognár József (2005): A testnevelés szerepe az egészségtudatos magatartás kialakításában, Új Pedagógiai Szemle, 6, 25-32.

Solymosi, K. (2004): Fejlődés és szocializáció. In. N. Kollár Katalin és Szabó Éva (szerk.): Pszichológia Pedagógusoknak, Budapest, Osiris Kiadó, 29-50.

Szombathelyiné Nyitrai Ágnes Anikó, Darvay Sarolta (2013): A mese és a játék jelenléte a kisgyermekes családok életében. In: Iskolakultúra, 23, 73-85. 